International Journal of Engineering \& Technology, $7(4.7)(2018) 123-126$
International Journal of Engineering \& Technology
SPC
Website: www.sciencepubco.com/index.php/IJET
Research paper

\title{
Research of the Technology for the Production of Modified Sulfur Bituminous Binders
}

\author{
R. Djimasbe, A.F. Kemalov, R.A. Kemalov \\ Kazan Federal University \\ *Corresponding author E-mail: richarddjimasbe@yahoo.fr \\ Telephone : +79083429647
}

\begin{abstract}
In this article, a review of the literature on the technology of production of a paving material based on elemental sulfur was made, and a laboratory test of this technology was carried out at the Department of Highly Viscous Crude Oil and Natural Bitumen. Attempts to mix sulfur with bitumen in order to reduce the cost of road construction and sulfur utilization were undertaken earlier, however, the mixtures obtained did not provide the appropriate quality, and the process was difficult to implement. The article proposes a unique technology for obtaining not a physical mixture, but the formation of a chemical bond between sulfur and bitumen with the formation of bitumen polymers. This technology becomes possible with the use of a catalyst specially developed by the initiators of the project and has no analogues in the world practice. Thus, the scientific novelty of the study is determined by the fact that for the first time an analysis is made of the composition of the components of the complex, which are subsequently introduced into the mixture with the feedstock in order to obtain the target product, which is gray-bitumen.
\end{abstract}

Keywords: Sulfur Bitumen, Sulfur concrete, Bitumen, Sulfur, Modifier, Polymer.

\section{Introduction}

In recent years, great attention has been paid to the modernization of technologies for the production of binding materials for paving, which contributes to the increase in the life of roads. From the technical and economic point of view, road bitumen is one of the most important and cheapest oil products, depending on its production and application in various fields, such as: road and airfield infrastructure; sealing of building products; for the roof, as well as the insulation system of pipelines.

Given the market competitive ability of commodity petroleum products, as well as the impact of the crisis on energy, early in 2000, scientific research began to develop intensively, including the search for new technological approaches to solving technoeconomic and environmental problems associated with road surfaces, which are of primary interest for all states and manufacturing enterprises. These events are reflected in the research work of several developed countries and a large manufacturing company, such as Shell Oil Company [1], on the production of paving materials using an elemental sulfur modifier that behave as a polymer compound in bitumen.

Ways were found to solve this problem, which are based on the use of elemental sulfur and hydrocarbon components. Certain aspects of the problem were raised in chemical works on the development of the catalytic complex of this part of the work.

However, the comparative result of this method with the usual in this case have the same value (By evaluation, this technology is economical and environmentally safe.) Author of the project VB Ivanov, a chemist-technologist, author of more than 50 publications, where 20 of them are patents and author's certificates from 1975 to 2001, he worked at the Institute of Organic and Physical
Chemistry named after A E Arbuzov of the Kazan Scientific Center of the Russian Academy of Sciences.).

The expediency of such technology is due to its unique properties, availability, low cost, soft condition. Gray-bituminous binders (SBV) are distinguished by high oxidative stability [2, 3, 4]. In France, about $10 \mathrm{~km}$ of asphalt concrete is produced for the experimental road coatings annually using a technology that temporarily mixes the molten sulfur with the heated bitumen, followed by treatment with this astringent mineral material. Some of the properties of bituminous mixes that can be improved using polymers are: increased resistance to stripping [2].

The percentage of sulfur in the bitumen depends on the cost of sulfur itself and the required quality of the product, including gray bitumen. So, in Saudi Arabia, a complex of scientific research works was carried out to identify the possibilities of using dune sands in asphalt mixtures. It has been revealed that the introduction of $15 \%$ sulfur into a mixture of dune sand with high viscosity bitumen (HVB) allows not only to reduce the optimum bitumen content from 6.4 to $5 \%$, but also improves the physical and mechanical properties of this product [5]. It is for this reason that the purpose of our research work will, in the future, be more closely related to sulfur-based polymer compounds, in other words, sulfur bitumen.

\section{Production and Consumption of Paving Ma- terials}

The world production of oil bitumen in 2001 was 111.5 million tons. The share directly for Russia is $9.1 \%$ of the global production capacity of petroleum bitumen.

In the world, especially in Russia, as well as in several central African developing countries such as the Republic of Chad, Nige- 
ria, Cameroon, Gabon, etc., the issue of road sector development (production of road bitumen) is topical, and the strengthening of its

Sustainability remains very promising [6]. The major manufacturers of bitumen binders based on heavy oils, natural bitumen and mineral resins in the Russian Federation include: OJSC "Asphaltconcrete plant No. 1", OAO "PKO" Chelyabinsk-Stroyindustriya ", OOO" JV "Fonika", ZAO "Beton", CJSC "Asphalt-concrete plant № 4" Kpotnya ". The question concerning the technology of production of sulfur-bitumen in Russia is, in practice, significantly important. According to practical data, only $10000 \mathrm{~m} 2$ of roadbed is covered with sulfur bitumen and gray-asphalt concrete.

In the Republic of Tatarstan, the technology of production of sulfur bitumen is based on the use of a special catalyst and some special products from oil refining. According to the assessment, this technology is economical and environmentally safe. Author of the project V.B. Ivanov, a chemical engineer, author of more than 50 publications, where 20 of them are patents and author's certificates (From 1975 to 2001, he worked at the Arbuzov Institute of Organic and Physical Chemistry, Kazan Scientific Center of the Russian Academy of Sciences.)

The technology itself is attractive and relevant, since the use of sulfur in the maximum percentage ratios to raw materials up to $40 \%$ makes it possible to reduce the cost of production from 30 to $40 \%$. When using a complex catalyst, S8 sulfur is activated by the mechanism for breaking the bond of the S8 molecule. In Table 2.1. Comparative characteristics of sulfur concrete and cement concrete.

Table 2.1:. Comparative characteristics of sulfur concrete and cement concrete

\begin{tabular}{|c|c|c|}
\hline Characteristics & $\begin{array}{c}\text { Cement } \\
\text { Concrete }\end{array}$ & $\begin{array}{c}\text { Gray } \\
\text { concrete }\end{array}$ \\
\hline Density on compression, MPa & $20-40$ & $85-102$ \\
\hline Flexural strength, MPa & $3-7,5$ & $10-30$ \\
\hline Ultimate strength, MPa & $2-4$ & $13-22$ \\
\hline Durability time & 28 days & $1-1.2$ hours \\
\hline $\begin{array}{c}\text { Coefficient of thermal expansion, mln cm } \\
\text { / s }\end{array}$ & $27,5-32,5$ & $0,25-2,5$ \\
\hline Coefficient of thermal conductivity & $1,2-1,4$ & $0,05-0,11$ \\
\hline Chemical resistance, & Low & High \\
\hline Water permeability, million cm / s & $1 / 1$ & Waterproof \\
\hline
\end{tabular}

Table 2.2:. Calculation of the cost of cubic meter based on composition

\begin{tabular}{|c|c|c|c|}
\hline $\begin{array}{c}\text { The name of indi- } \\
\text { cators }\end{array}$ & $\begin{array}{c}\text { Cost of a ton of } \\
\text { Components, } \\
\text { rubles. }\end{array}$ & $\begin{array}{c}\text { Content in } \\
\text { cubic meter } \\
\text { of concrete } \\
\text { mixture, rub. }\end{array}$ & $\begin{array}{c}\text { Cost of cubic } \\
\text { meter of con- } \\
\text { crete, rub. }\end{array}$ \\
\hline $\begin{array}{c}\text { Portland cement } \\
\text { M400 }\end{array}$ & 4500 & 400 & 1800 \\
\hline Sand quartz & 300 & 650 & 195 \\
\hline Crushed gravel & 800 & 1100 & 880 \\
\hline Water & & 150 & 150 \\
\hline Total & & & 3025 \\
\hline $\begin{array}{c}\text { Gray concrete } \\
\text { on technical sulfur }\end{array}$ & 500 & 350 & 175 \\
\hline Sulfur & 400 & 400 & 160 \\
\hline $\begin{array}{c}\text { Screening of } \\
\text { crushing of car- } \\
\text { bonate crushed } \\
\text { stone }\end{array}$ & 300 & 250 & 75 \\
\hline Sand quartz & & & 410 \\
\hline Total & & & \\
\hline
\end{tabular}

The production of sulfur concrete in large volumes is extremely dangerous: first, the question arises of the need for strict protection; secondly, sulfur is oxidized by sulfur bacteria and soil poisoning by sulfuric acid can occur. So with the help of technology invented by VB. Ivanov, one can also solve serious environmental issues. To date, a plant for the production of sulfuric compositions has been assembled; specialized laboratory samples of sulfur concrete and gray-asphalt-concrete coatings have been obtained.
There are questions on the introduction of technology; the technology of production of sulfur concrete is interesting because it allows you to obtain innovative materials at prices below the traditional ones. In this regard, we can expect that the sulfur-concrete, given their clear advantage over concrete on Portland cement and asphalt concrete, will have a fairly stable sale. In the new material, sulfur is used together with the cement, with the additive-modifier of a specific design. Advantages of this material are its low water permeability and high corrosion resistance, which is especially important for the acid medium (Table 1.2). In 10\% sulfuric acid, it retains its property for three years. Gray concrete quickly gaining strong characteristics (2-3 hours, normal concrete 28 days). Strength values of sulfur concrete on compression, bending is much better than that of ordinary concrete, it also features high inertia, zero water permeability, high coefficient of adhesion. It should be noted that the properties of sulfur concrete are more dependent on the technological process and quality control of the output raw materials throughout the production phase. In order to produce Gray concrete with industrial volumes, the following equipment is required:

- Drum dryer;

- a reactor for mixing inert materials and sulfur;

- the pump;

- molding equipment such as a carousel and a vibrating pad; - hangars for raw materials.

\section{Comparative Assessment of the Quality of Russian and Foreign Bitumen}

The United States is one of the largest countries that produce sulfur bitumen; there is widespread use of asphalt concretes with the addition of sulfur. Gray-bitumen binder is used in different types of fitness, such as new construction. Repair of road surfaces. Research and development of technology has been carried out together with Canadian firms and the US mining industry laboratory.

Canadian experts and authors were convinced that the amount of sulfur affects the characteristics and properties of sulfur-bitumen, and the attention of researchers is more focused on the method of obtaining preliminary mixtures of sulfur-bitumen. There are two methods of using sulfur in the road bituminous layer of ore materials: with a minimum amount of sulfur in the form of a bitumen diluent in conventional asphalt concrete. The results of the research showed that under such a technological regime it is possible to prepare binders (mixtures based on it) containing up to $30 \%$ sulfur in bitumen.

Since the density of sulfur is much higher than the density of bitumen, the consumption of sulfuric binder for the preparation of asphalt mixtures is slightly higher than in bituminous mixtures; a large amount of sulfur is used and as a filler mixture.

In the northern US states in winter, the temperature can reach minus $30^{\circ} \mathrm{C}$ and in order to improve the low-temperature properties of asphalt-concrete coatings, an astringent bitumen with a penetration depth of 250-350 mm-1 (Asphalt road oil bitumen: BND 250/350) at $25^{\circ} \mathrm{C}$ is used as an organic component. It introduces up to $20 \%$ sulfur, which increases the thermal stability of the binder, and hence the shear stability of such road surfaces during the summer operating period. The following table shows a comparison of the GOST standards of the Russian the graybitumen obtained by us in its application in road construction is given in Table 3.1 
Table 3.1: Analyzes are carried out and certified in the laboratory (VSK2000 LLC, testing laboratory of GU GLAVTATDORTRANS and laboratoryof

\begin{tabular}{|c|c|c|c|}
\hline Name indicators & $\begin{array}{c}\text { Norms } \\
\text { GOST } \\
2245-90\end{array}$ & \multicolumn{2}{|c|}{$\begin{array}{l}\text { Actual values of indi- } \\
\text { cators } \\
\text { gray-bitumen }\end{array}$} \\
\hline $\begin{array}{l}\text { The penetration depth } \\
\text { of the needle, } 0.1 \mathrm{~mm} \text { : } \\
\text { - at } 25^{\circ} \mathrm{C} \\
\text { at } 0^{\circ} \mathrm{C}\end{array}$ & $\begin{array}{l}\text { no less } \\
\text { than } \\
90-130 \\
28 \\
\end{array}$ & 110 & $\begin{array}{l}79 \\
20 \\
\end{array}$ \\
\hline $\begin{array}{l}\text { Softening temperature by } \\
\text { ring and ball, } 0 \mathrm{C}\end{array}$ & 47 & 49 & 48 \\
\hline $\begin{array}{c}\text { Extensibility, cm, not less } \\
\text { than: } \\
\text { - at } 25^{\circ} \mathrm{C} \\
\text { at } 0^{\circ} \mathrm{C}\end{array}$ & $\begin{array}{c}65 \\
4,0\end{array}$ & $\begin{array}{c}\text { More } \\
\text { than } \\
65 \\
3.0\end{array}$ & $\begin{array}{l}120 \\
3,5\end{array}$ \\
\hline Brittleness temperature 0C & -17 & - & -18 \\
\hline $\begin{array}{l}\text { Weight change after } \\
\text { warming up, } \%\end{array}$ & 5 & 4,5 & 5 \\
\hline Penetration index & $\begin{array}{l}\text { From }-1,0 \\
\text { to }+1,0\end{array}$ & $+0,8$ & $-0,58$ \\
\hline
\end{tabular}

\section{Physical and Chemical Processes of Interac- tion of Sulfur and Bitumen. Factors Affecting the Properties of Sulfur-Bituminous Binders}

The interaction of sulfur and organic compounds has not been studied to date. Considering the significant range of sulfur influence, an important role is played by the mechanism of processes arising from the interaction of sulfur with bitumen and the conditions for the implementation of these processes. Sulfurization reactions are impeded by the complexity of the structure of sulfur itself, its reactivity rapidly acts in some directions with increasing formation of hydrogen sulphides and polysulfones, causes additional secondary reactions (polymer-hydrogenation, condensation).

Depending on the chemical interaction of sulfur with bitumen, sulfur-carbon bonds are formed, respectively, after the interaction of sulfur with unsaturated hydrocarbons of resin components and alkenes. Elemental chemical compositions of resins are constituent parts of aromatic rings, naphthenic and heterocyclic rings between them, which are primarily components of interaction with sulfur $[7,8,9,10]$. As a result of sulphonation reactions, the resin content decreases and the content of the leading high-molecular compounds increases, and consequently the content of the dispersed phase (asphaltenes) in the binder increases.

Sulfur has a very high chemical activity compared to hydrocarbons contained in bitumen.

The reason for this effect on the interaction of sulfur with bitumen is the temperature where, at some temperature limit, the oligomers contained in bitumen begin to react with sulfur at temperatures above $130^{\circ} \mathrm{C}$, as well as compounds saturated at a temperature of $140-150{ }^{\circ} \mathrm{C}[11,12,13]$.

In the interaction of sulfur with bitumen, two basic chemical reactions occur:

- At temperatures up to $140{ }^{\circ} \mathrm{C}$, the result of the interaction of sulfur with bitumen is the formation of polysulfide compounds. The most active bonds appear with aromatic naphthalenes. There is a plasticizing effect, an increase in penetration and a decrease in the softening temperature of the SBC. The content of asphaltenes does not change;

- At temperatures above $140{ }^{\circ} \mathrm{C}$, dehydrogenation reactions of bituminous bonds proceed and hydrogen sulphide is released. Dehydrogenated chains are given cyclization, leading to an increase in the content of asphaltenes. At the same time, sulfur dioxide is released due to the oxidation of sulfur by air oxygen and oxygen from heteropoly asphaltenes [14].

\section{Technical Properties of Sulfur}

Sulfur is a chemical element of Group VI of the Periodic Table of Elements. Mendeleev with an atomic mass of 32.06 and a density of $2.1 \mathrm{~g} / \mathrm{cm} 3$. The melting point of sulfur is $110-119^{\circ} \mathrm{C}$, boiling $444.8^{\circ} \mathrm{C}$. Sulfur weakly conducts electric current, does not dissolve in water and in most inorganic acids, dissolves well in carbon disulfide, anhydrous ammonia, aniline, potassium hydroxide and other organic solvents. The thermal conductivity of solid and liquid sulfur is low, therefore a considerable amount of energy is required for its melt and heating in the range of $190 \mathrm{~kJ} / \mathrm{g}$ per 1 $\mathrm{kg}$ of solid sulfur. The main properties of sulfur are given in the table. $5.1[7-9]$.

Table.4.1. The proprieties of sulfur

\begin{tabular}{|c|c|c|c|}
\hline Indicator & \multicolumn{3}{|c|}{ Temperature, ${ }^{0} \mathrm{C}$} \\
\hline Density, g / cm3 & $\mathbf{2 0}$ & $\mathbf{1 2 2}$ & $\mathbf{1 5 0}$ \\
\hline Compression strength, MPa & 2,1 & $1,96-1,99$ & $1,6-1,81$ \\
\hline Moss hardness & $12-22$ & - & - \\
\hline Viscosity, Pa * s & $1-2$ & $\begin{array}{c}0,011- \\
0,012\end{array}$ & $\begin{array}{c}0,0065- \\
0,0070\end{array}$ \\
\hline Over tension / m & - & - & 0,065 \\
\hline Specific heat, KJ / kg & 0,7 & 1,47 & 1,84 \\
\hline
\end{tabular}

Sulfur can be in three states depending on temperature: solid, liquid and gaseous. The structure of sulfur molecules and their reactivity depends on temperature. At a temperature of $159.4^{\circ} \mathrm{C}$, almost all the properties of liquid sulfur undergo changes. The most significant change undergoes viscosity. At $117^{\circ} \mathrm{C}$, the viscosity of pure sulfur is $0.011 \mathrm{~Pa} \cdot \mathrm{s}$. With increasing temperature, the viscosity of sulfur first decreases, reaching a minimum at $155^{\circ} \mathrm{C}$ $-0.0065 \mathrm{~Pa} \cdot \mathrm{s}$.

Beginning at $158^{\circ} \mathrm{C}$, liquid sulfur becomes brown, its viscosity increases and at $187^{\circ} \mathrm{C}$ it reaches a maximum value of $93.3 \mathrm{~Pa}$. s. With a further increase in temperature, the viscosity of sulfur decreases, and at $400^{\circ} \mathrm{C}$ it becomes $0.16 \mathrm{~Pa} \cdot \mathrm{s}$. Such an anomalous change in viscosity is associated with a change in the molecular structure of sulfur. At ordinary temperatures, sulfur consists of eight atomic ring molecules, which begin to break at a temperature of $155-160{ }^{\circ} \mathrm{C}$, which leads to a decrease in viscosity. Then, the ring atoms of the emerging open structures are connected to each other, forming long chains of several thousand atoms.

This is accompanied by a sharp increase in viscosity. Further heating leads to the breaking of the chains, as a result of which the viscosity decreases.

The molecular structure of sulfur is distinguished by a very large variety of polymorphic modifications. At present, more than thirty allotropes of sulfur have been isolated, most of them have not been sufficiently studied, and their single classification is still lacking $[7,8,15]$.

\section{Conclusion}

A review of literature data from various sources on the use of sulfur in waste. They say that sulfur, introduced into bitumen, is in two states: liquid and solid. The relationship between the amount of liquid state and crystalline sulfur depends on a number of factors: the chemical composition and the dispersed structure of bitumen, the temperature of the mixture and the time, beginning with the introduction of sulfur. The addition of sulfur leads to the formation of a highly dispersible astringent secondary structure, the type of which depends on the mass content of sulfur in the SBW. A small addition of sulfur (up to $15 \%$ ) contributes to the formation of a coagulation structure of coagulation. At a sulfur content of more than $30 \%$, with a decrease in temperature, the formation of the SBW not only coagulates, but also crystallizes. The crystallization structure reduces deformability, increases the stiffness and brittleness of the binder. Characteristics of modification of physical and mechanical properties of bitumen of various 
categories and types of structure, dispersed from sulfur content in SBW and rational doses of sulfur. It is shown that the addition of sulfur to $20 \%$ is equivalent to the introduction of a plasticizer. At higher doses (up to $30-40 \%$ ), sulfur is an additive that forms a structure that increases the viscosity and heat resistance, slightly reducing the crack resistance of the binder. Introduction of SBC temperature. preparation and compaction of bitumen-concrete mixtures.

The results given by us show that Serobitum can successfully replace ordinary bitumen in production. Asphal concrete shows the same and sometimes significantly more than usual bitumen.

The work is performed according to the Russian Government Program of Competitive Growth of Kazan Federal University.

\section{References}

[1] Tjah Sutandar \& Gaétan Poirier, Shell Oil Company : Les enrobes Bitumineux modifies au soufre. 23 mars 2012, - 30 c. http://www.bitumequebec.ca/wp-content/uploads/2015/06/14enrobes-bitumineux-modifies-au-soufre-g-poirier.pdf

[2] Abdelaziz Mahrez., and Mohamed Rehan Karim: Rheological Evaluation of Aging Properties of Rubber Crumb Modified Bitumen, Journal of the Eastern Asia Society for Transportation Studies, Vol.5, 2003.

[3] Slavutsky, M.S. Why did viscous bitumens bogged down/M.S. Slavutsky//Automobile roads - 2000.-№7. - Page 24-25.

[4] Sokhadze, V.S. New opportunities of bituminous materials / V.S, Sokhadze//Construction and real estate. - 2001.-№ 2. - Page 25-29.

[5] Rudenskaya, I.M Organic knitting for road construction / I.M Rudenskaya, A. V. Rudensky - M.: Transport, 1984.-229 pages.

[6] 'Vernoye Resheniye' magazine, Evgeny. M, engineer and patent engineer of VOIR: Relevance of production of gray concrete and gray bitumen. Use of sulfur in road construction of the USA, Canada, France, Poland, See: 01.12.2017 3 pm, http://www.xn---dtbhaacat8bfloi8h.xn--p1ai/serobeton-actual

[7] Dzhimasbe P, Fakhrutdinov R. Z, Galiullin E. A., Laskovenokova E. A.: About a role of oil production and oil processing in economy of the Republic of Chad, the Bulletin of the Kazan national technological university. 2017 V.20, No. 3

[8] Menkovsky M.A. Technology of sulfur / M.A. Menkovsky, V.T Yavorsky. - M.: Chemistry, 1985. - 286th page 2. Haliullin A.K. Sulfur(s) chemistry. K. Haliullin. - M.: Stroyizdat, 1995. - 170 pages.

[9] Haliullin A.K. Sulfur(s) chemistry. K. Haliullin. - M.: Stroyizdat, 1995. - 170 pages.

[10] Lyapina N.K. Chemistry and physical chemistry of organosulfur compounds of oil distillates / N.K. Lyapina. - M.: Science, 1984. 120 pages.

[11] Influence of technological parameters on interaction of sulfur with oil residues / I.R. Telyashev, etc.//Oil processing and petrochemistry: ref.book. IPNHP. - Ufa: IPNHP publishing house, 2001. - Issue 33. - Page $76-81$

[12] Tomkowiak K. Wplyw dodatky sidrky do asphaltow / K. Tomkowiak, K. Zelinski // Drogownictwo. - 1983. - № 2. - S. 55 - 59.

[13] Stefanczyk B. Wplum siarki na rozne rodzaje asfaltow / B. Stefanczyk // Drogownictwo. - 1985. - № 5. - S. 142 - 158.

[14] Kalabinska M. Technologia materialow I nawierzchni drogowych / M. Kalabinska, J. Pilat. - Warszawa, 1985. - 235 s.

[15] Sidorenko N.N. Extension of a lifelength of road asphalt concrete coverings in the conditions of Far North: Autoref. Cand.Tech.Sci. / N.N. Sidorenko. - M, 1987. -20 p.

[16] Borbat V.F. Sulfur chemistry in technology of industrial materials / V.F. Borbat, M.A. Elesin, F.P. Turenko. - Omsk: Akademia publishing house, 2004. -274 pages. 